\title{
PENGARUH PEMBERIAN ABU BATUBARA SEBAGAI SUMBER SILIKA (SI) BAGI PERTUMBUHAN DAN PRODUKSI TANAMAN PADI (Oryza sativa L)
}

\author{
Teguh Budi Prasetyo, Syafrimen Yasin, dan Edri Yeni \\ ${ }^{1}$ J urusan Tanah F akultas Pertanian U niversitas Andalas
}

\begin{abstract}
A research about use of coal ash as a silicate source for rice production was conducted in Greenhouse at Agriculture Faculty of Andalas University from October 2006 to February 2007. The objective of this research was to study the effect of coal fly ash as silicon (Si) sources for the growth and production rice crops (Oryza sativa L.). The experiment was designed on Completely Randomized Block Design with four treatments and three replications. The treatments consist of ; 0 ton/ha, 20 ton/ha , 40 ton/ha and 60 ton/ha coal fly ash. The result showed that, fly ash from coal burning could increase available fosfor and reduce dissolved aluminum in the soil. Fly ash could also increase crop production, P- and Si-absorption by crops.
\end{abstract}

Key Words: coal fly ash, silicate, rice crops

\section{PENDAHULUAN}

Tanaman padi (Oryza sativa L.) mempunyai peranan penting dalam hal ketahanan pangan di Indonesia. Untuk meningkatkan ketahanan pangan pencapaian produksi beras yang optimal mutlak diusahakan melalui peningkatan produktifitas padi. Salah satu usaha meningkatkan produktifitas tanaman padi pemerintah Indonesia mengadopsi konsep Green Revolution (Revolusi hijau) yang kita kenal dengan usaha intensifikasi melalui badan Bimas.

Penelitian tentang pengaruh penggunaan Revolusi Hijau antara tahun 1970 - 2003 terhadap perubahan sifat tanah sawah di Pulau Jawa, dimana teknologi ini telah digunakan pertama kali, menunjukkan bahwa intensifikasi penanaman padi yang disertai dengan penggunaan pupuk kimia seperti Urea dan SP-36 telah menunjukkan proses pemasaman tanah dan penumpukan fosfor dalam tanah. Penelitian ini juga menemukan bahwa kandungan silika tersedia dalam tanah berkurang sekitar $20 \%$ dalam waktu kurun waktu yang sama, diduga sebagai penyebab terjadinya stagnansi produksi padi di Indonesia (Darmawan,2005).

Silika sebagai unsur hara non essensial luput dari perhatian pemerintah dan para petani sawah. Ini terbukti dengan tidak adanya penambahan Si secara artifisial dalam praktek bercocok tanam padi selama ini. Perpindahan Si keluar areal persawahan melalui proses pemanenan dan erosi tanpa diiringi dengan penambahan $\mathrm{Si}$ secara artifisial diduga merupakan faktor utama dalam proses penurunan kandungan $\mathrm{Si}$ tersedia dalam tanah (Otsuka, 2000 dan Kyuma, 2004 cit Darmawan, 2005). Oxisol merupakan tanah yang telah mengalami pelapukan lanjut dan banyak terdapat di daerah tropis/subtropis. Biasanya dijumpai pada permukaan tanah yang telah berumur tua. Penyebaran jenis tanah ini antara lain di Jawa, Sumatera, Kalimantan dan Sulawesi. (Situmorang dan Sudadi, 2001).

Proses desilikasi pada Oxisol ini membuat unsur silika ini semakin berkurang. Desilikasi adalah proses pembentukan tanah yang menyebabkan silika yang terdapat pada lapisan atas tanah tercuci ke lapisan bawah, sehingga kadar silika pada lapisan atas menurun, sedangkan oksida-oksida besi dan Aluminium terakumulasi pada permukaan tanah. Semakin tinggi kandungan Al dan besi oksida di dalam tanah mengakibatkan $\mathrm{Si}$ yang terlarut atau tersedia menjadi rendah (Hardjowigeno, 1993). Abu sisa pembakaran batubara jenis abu terbang (fly ash) adalah jenis bahan yang mengandung $\mathrm{Si}$ tinggi dan telah digunkan sebagai sumber $\mathrm{Si}$ untuk tanaman padi di berbagai negara (Komdorfer dan Lepsch, 2001). Sejauh ini 
pemanfaatan batubara yang semakin meningkat akibat naiknya harga bahan bakar minyak (BBM) juga menyisakan masalah baru terhadap lingkungan. Ketersediaan yang melimpah serta kandungan $\mathrm{Si}$ yang tinggi menyebabkan limbah ini berpotensi besar sebagai sumber silika untuk tanaman padi. Hasil analisis yang dilakukan oleh PLTU Sijantang (1998 cit Irmayanti, 2000),abu batubara mengadung 3,94\% $\mathrm{MgO} ; 7,90 \% \mathrm{CaO}$; $3,14 \% \mathrm{NaO}, 24,4 \% \mathrm{SiO}_{2} ; 8,60 \% \mathrm{Fe}_{2} \mathrm{O}_{3}$; $23,02 \% \mathrm{Al}_{2} \mathrm{O}_{3} ; 3,82 \% \mathrm{SO}_{3} ; 0,24 \% \quad \mathrm{P}_{2} \mathrm{O}_{5}$ dan $1,52 \% \mathrm{~K}_{2} \mathrm{O}$.

Penelitian ini bertujuan mempelajari pengaruh pemberian takaran abu batubara sebagai sumber silika terhadap pertumbuhan dan produksi tanaman padi serta untuk mendapatkan takaran optimum untuk pertumbuhan dan produksi tanaman padi. Berdasarkan kandungan hara dalam abu batubara memungkinkan dapat mengatasi masalah kekurangan silika pada tanah sawah dan mendukung pertumbuhan dan produksi tanaman padi.

\section{BAHAN DAN METODA}

Contoh Tanah.

Contoh tanah telah diambil di daerah Sirukan Kecamatan Payung Sekaki Kabupaten Solok. Pengambilan tanah dilakukan secara komposit pada kedalaman $0-20 \mathrm{~cm}$ dari permukaan tanah. Penelitiannya menggunakan Rancangan Acak Lengkap (RAL) dengan 4 perlakuan ( tanpa perlakuan +3 takaran abu batubara) dengan 3 ulangan yang dilakukan dalam bentuk percobaan pot di rumah kaca.
Adapun perlakuannya terdiri dari : A) tanpa abu batubara, B) 20 ton/ha abu batubara $(0,80 \mathrm{~kg} / 10 \mathrm{~kg}$ tanah $)$, C) 40 ton/ha abu batubara $(0,160 \mathrm{~kg} / 10 \mathrm{~kg}$ tanag $)$, D) 60 ton/ha abu batubara $(0,240 \mathrm{~kg} / 10 \mathrm{~kg}$ tanah. Analisis tanah yang dilakukan adalah analisis tanah awal dan analisis setelah inkubasi, meliputi analisis $\mathrm{pH} \mathrm{H}_{2} \mathrm{O}(1: 1)$ dan $\mathrm{pH} \mathrm{KCl}(1: 1)$ diukur dengan $\mathrm{pH}$ meter, $\mathrm{C}$-organik dengan metode Walkey and Black, \% $\mathrm{N}$ total dengan metode Kjeldhal, $\mathrm{P}$ tersedia ditentukan dengan metode Bray II, kadar $\mathrm{Ca}, \mathrm{Mg}, \mathrm{K}$ dan $\mathrm{Na}$ yang dapat dipertukarkan dengan metode pencucian dengan Ammonium asetat $\mathrm{pH} 7$, kandungan Si ditentukan dengan metode buffer asetat.

\section{Contoh Tanaman.}

Pengamatan pada tanaman adalah tinggi tanaman setelah tanaman berumur 2 minggu dan pengukuran selanjutnya sekali seminggu hingga pertumbuhan vegetatif maksimal, pengamatan jumlah anakan total diamati pada saat umur tanaman 7 minggu atau pada pertumbuhan vegetatif maksimal, pengamatan jumlah anakan produktif dilakukan pada saat mendekati tanda-tanda matang panen, perhitungan berat 1000 butir gabah. Analisis tanaman yang dilakukan adalah analisis serapan P dan serapan Si.

\section{HASIL DAN PEMBAHASAN}

Analisis Tanah Awal.

Dari penelitian yang telah dilakukan didapatkan hasil analisis tanah awal beberapa sifat kimia Oxisol pada Tabel 1.

Tabel 1. Hasil analisis tanah awal pada Oxisol nagari Sirukam Kabupaten Solok

\begin{tabular}{|c|c|c|}
\hline Jenis Analisis & Nilai & Kriteria* \\
\hline $\mathrm{pH} \mathrm{H} \mathrm{H}_{2} \mathrm{O}$ & 4.02 & Sgt masam \\
\hline $\mathrm{pH} \mathrm{KCl}$ & 3.72 & - \\
\hline P-tersedia (ppm) & 36.73 & Sedang \\
\hline Si-_tersedia ppm) & 17.58 & Sgt kurang ** \\
\hline Ca-dd (me/100g) & 0.52 & Rendah \\
\hline Mg-dd (me/100g) & 1.66 & Rendah \\
\hline $\mathrm{K}$-dd (me/100g) & 3.38 & Rendah \\
\hline $\mathrm{Na}-\mathrm{dd}(\mathrm{me} / 100 \mathrm{~g})$ & 0.86 & Rendah \\
\hline $\mathrm{Al}-\mathrm{dd}(\mathrm{me} / 100 \mathrm{~g})$ & 5.15 & - \\
\hline Kej. Al ( \%) & 44.51 & Tinggi \\
\hline
\end{tabular}


Hasil analisis tanah diatas dapat dikatakan bahwa reaksi tanah tergolong sangat masam, P-tersedia termasuk kategori sedang, Sitersedia sangat kurang, kation basa tergolong rendah, kejenuhan Aluminium termasuk tinggi. Jadi dapat dikatakan bahwa tanah untuk penelitian ini mempunyai sifat kimia yang jelek dan kesuburan yang rendah.

Kejenuhan Al yang tinggi merupakan faktor pembatas pertumbuhan dan perakaran tanaman yang menyebabkan tanah bereaksi masam (Adam dan Parkinson, 1967). Hal ini sesuai dengan apa yang dikatakan oleh Hardjowigeno (1986), masalah utama yang ditemukan pada Oxisol adalah reaksi tanah yang masam, erat hubungannya dengan aktifitas $\mathrm{Al}, \mathrm{Fe}, \mathrm{Mn}$, rendahnya P-tersedia, basa yang dapat dipertukarkan rendah dan tingkat kesuburan yang rendah.

\section{Analisis Contoh Tanah Setelah Inkubasi}

Hasil analisis contoh tanah setelah diinkubasi dengan abu batubara selama 4 minggu dapat dilihat pada Tabel 2 :

Dari Tabel 2 dapat dikatakan bahwa dengan takaran 0,20, 40, 60 ton/ha terjadi sedikit peningkatan nilai $\mathrm{pH}$ sebesar masingmasingnya 0,$23 ; 0,37 ; 0,42$ satuan yang termasuk ke dalam criteria sangat masam.

Peningkatan $\mathrm{pH}$ terjadi karena abu batubara mengandung $\mathrm{CaO}$ dan $\mathrm{MgO} 3$, dimana $\mathrm{CaO}$ dan $\mathrm{MgO}$ dapat menetralisisr ion-ion $\mathrm{H}^{+}$yang berasal dari dalam tanah dengan demikian semakin tinggi takaran abu batubara yang diberikan, maka semakin besar jumlah $\mathrm{CaO}$ dan $\mathrm{MgO}$ yang diberikan ke dalam tanah, sehingga penetralan ion-ion
$\mathrm{H}^{+}$yang berasal dari dalam tanah juga semakin banyak.

Abu batubara dapat meningkatkan ketersediaan P (Tabel 2), dimana dari Tabel 2 dapat dikatakan bahwa terjadi peningkatan ketersediaan $\mathrm{P}$ seiring dengan peningkatan perlakuan abu batubara. Peningkatan maksimum terjadi pada perlakuan 60 ton/ha dengan nilai sebesar 8,67 ppm dibandingkan dengan tanpa perlakuan. Hal ini diduga karena silikat dapat menggantikan posisi $\mathrm{P}$ yang berada pada tapak jerapan,sehingga anion $\mathrm{P}$ akan dikeluarkan ke dalam larutan tanah dan tapak jerapan akan ditempati oleh silikat.

Pemberian silikat dapat meningkatkan kadar P tanah menjadi bentuk yang lebih tersedia bagi tanaman. Sanchez dan Uchara (1980) melaporkan bahwa natrium silikat yang diberikan ke dalam tanah akan terurai sebagai berikut :

$\mathrm{NaH}_{3} \mathrm{SiO}_{4} \rightarrow \mathrm{Na}^{+}+\mathrm{H}_{3} \mathrm{SiO}_{4}^{-}$

Dalam proses pembebasan fosfat yang disorpsi oleh komponen-komponen tanah,anion silikat akan menggantikan fosfat melalui proses pertukaran anion.

Abu batubara dapat meningkatkan kandungan silika dalam tanah, dimana dari Tabel 2 didapat bahwa peningkatan terjadi seiring dengan peningkatan pemberian abu batubara.. Pemberian abu batubara sebagai sumber silika berarti semakin banyak $\mathrm{Si}$ diberikan, maka sebagian Si akan terserap pada tapak jerapan dan sebagian akan tetap larut dalam larutan tanah, namun kejadian ini memberikan pengaruh yang positif terhadap ketersediaan P.

Tabel 2: Hasil analisis tanah setelah inkubasi dengan pemberian abu batubara

\begin{tabular}{ccccc}
\hline Jenis analisis & Tnp AS & $\begin{array}{c}800 \\
\mathrm{~kg} / \mathrm{ha}\end{array}$ & $\begin{array}{c}1600 \\
\mathrm{~kg} / \mathrm{ha}\end{array}$ & $2400 \mathrm{~kg} / \mathrm{ha}$ \\
\hline $\mathrm{pH} \mathrm{H} \mathrm{H}_{2} \mathrm{O}$ & $4,04 \mathrm{sm}$ & $4,27 \mathrm{sm}$ & $4,41 \mathrm{sm}$ & $4,46 \mathrm{sm}$ \\
P-tsedia & $36,59 \mathrm{~s}$ & $38,73 \mathrm{t}$ & $42,12 \mathrm{t}$ & $45,26 \mathrm{t}$ \\
Si-terdia & $22,84 \mathrm{sk}$ & $49,21 \mathrm{k}$ & $60,62 \mathrm{k}$ & $70,89 \mathrm{c}$ \\
K-dd & $0,53 \mathrm{~s}$ & $0,54 \mathrm{~s}$ & $0,57 \mathrm{~s}$ & $0,63 \mathrm{~s}$ \\
$\mathrm{Na}-\mathrm{dd}$ & $1,52 \mathrm{r}$ & $1,59 \mathrm{r}$ & $1,81 \mathrm{r}$ & $2,05 \mathrm{r}$ \\
$\mathrm{Ca}-\mathrm{dd}$ & $3,22 \mathrm{r}$ & $3,32 \mathrm{r}$ & $3,38 \mathrm{r}$ & $3,51 \mathrm{r}$ \\
$\mathrm{Mg}-\mathrm{dd}$ & $0,83 \mathrm{r}$ & $0,83 \mathrm{r}$ & $0,84 \mathrm{r}$ & $0,87 \mathrm{r}$ \\
Kej. Al & $39,97 \mathrm{t}$ & $33,03 \mathrm{t}$ & $31,15 \mathrm{t}$ & $26,17 \mathrm{~s}$ \\
\hline
\end{tabular}

Sumber : * LPT Bogor (1983, cit Hardjowigeno 2003)

Keterangan : $\mathrm{sm}=$ sangat masam $\mathrm{r}=$ rendah $\mathrm{s}=$ sedang $\mathrm{t}=$ tinggi $\mathrm{sk}=$ sangat kurang $\mathrm{k}=$ kurang, $\mathrm{c}=$ cukup 
Pengaruh terhadap Ca-dd dan Mg-dd terhadap pemberian abu batubara juga meningkat seiring dengan peningkatan takaran perlakuan, walaupun pada kriteria yang masih rendah. Peningkatan Ca-dd dan Mg-dd maksimum terjadi pada perlakuan 60 ton/ha yaitu masing-masing sebesar 0,32 $\mathrm{me} / 100 \mathrm{~g}$ dan $0,05 \mathrm{me} / 100 \mathrm{~g}$ dibandingkan dengan tanpa perlakuan, sedangkan peningkatan maksimum K-dd dan Na-dd juga terjadi pada perlakuan 60 ton/ha yaitu masing-masing sebesar $0,10 \mathrm{me} / 100 \mathrm{~g}$ dan $0,53 \mathrm{me} / 100 \mathrm{~g}$. Peningkatan ini terjadi karena pada abu batubara mengandung $\mathrm{CaO}$, $\mathrm{MgO}, \mathrm{K}_{2} \mathrm{O}$ dan $\mathrm{Na}_{2} \mathrm{O}$ masing-masingnya sebesar7,90\%;3,94\%; 1, 52\% dan 24, $4 \%$.

Peningkatan nilai basa-basa yang dapat ditukarkan melalui pemberian abu batubara disebabkan oleh adanya basa-basa yang disumbangkan oleh batubara ke dalam Oxisol. Menurut Hakim et al (1986), unsur $\mathrm{Ca}$ dan $\mathrm{Mg}$ yang diberikan ke dalam tanah selain berfungsi untuk meningkatkan $\mathrm{pH}$ tanah, juga berfungsi sebagai sumber $\mathrm{Ca}$ dan $\mathrm{Mg}$ dalam tanah. Penambahan abu batubara ke dalam tanah berpengaruh secara langsung menambah konstribui $\mathrm{K}$ dan $\mathrm{Na}$ dalam larutan tanah. Kondisi ini menyebabkan meningkatnya kandungan $\mathrm{K}$ dan $\mathrm{Na}$ tanah:

Menurunnya kandungan Al-dd tanah diduga karena terjadinya peningkatan $\mathrm{pH}$ tanah. Senyawa- senyawa $\mathrm{OH}^{-}$di dalam tanah mampu mengikat $\mathrm{Al}^{+3}$ sehingga terbentuk senyawa $\mathrm{Al}(\mathrm{OH})_{3}$ yang bersifat mengendap. Keadaan ini menyebabkan terjadinya penurunan kandungan Al-dd tanah. Jones dan Handreck (1967 cit Hermansah (1993) menyatakan bahwa oksida-oksida $\mathrm{Al}$ mudah bereaksi dengan silikat yang larut. Kejadian ini juga dapat dihubungkan dengan apa yang dikatakan Iller (1995 cit Sari, 1998), asam polisilisik akan bereaksi dengan logam-logam yang sedikitnya mempunyai satu gugus hidroksil, hal ini memberikan peluang yang lebih besar terjadinya ikatan Si dan Al.

\section{Pertumbuhan Tanaman}

Hasil analisis pemberian abu batubara terhadap pertumbuhan dan serapan hara tanaman padi pada minggu ke-11 dapat dilihat pada Tabel 3 .

\section{a. Tinggi Tanaman}

Dari Tabel 3 dapat dikatakan bahwa pemberian abu batubara sebagai sumber silika terhadap parameter tinggi tanaman tidak berbeda nyata. Parameter tinggi tanaman tidak mencerminkan pengaruh perlakuan yang sebenarnya terhadap pertumbuhan tanaman.

Hal ini dapat dilihat dari tinggi tanaman yang sama antar perlakuan, namun jumlah anakan menunjukkan perbedaan yang nyata. Dari pengamatan langsung didapat bahwa pertumbuhan tanpa perlakuan lebih jelek dibandingkan perlakuan yang lain.

\section{b. Jumlah Anakan Produktif \\ Dari Tabel 3 abu batu bara} mempunyai pengaruh yang nyata antara tanpa perlakuan dengan perlakuan 20 ton/ha dan berbeda terhadap perlakuan 40 ton/ha, tetapi pada perlakuan 40 ton/ha dengan perlakuan 60 ton/ha memperlihatkan perbedaan yang tidak nyata sesamanya. Untuk perlakuan 40 ton/ha merupakan jumlah anakan produktif yang paling tinggi dengan tidak memperlihatkan pengaruh yang tidak nyata dengan tanpa perlakuan

Tabel 3. Pengaruh abu batubara sebagai sumber silika terhadap tinggi tanaman

\begin{tabular}{cccccc}
\hline $\begin{array}{c}\text { Abu } \\
\text { Batubara }\end{array}$ & Tinggi $(\mathrm{cm})$ & Anakan & Berat $(\mathrm{g})$ & $\begin{array}{c}\text { Serapan P } \\
\text { tanaman }\end{array}$ & $\begin{array}{c}\text { Serapan Si } \\
\text { tanaman }\end{array}$ \\
\hline Tanpa & $104,77 \mathrm{a}$ & $15,55 \mathrm{a}$ & $15,55 \mathrm{a}$ & $85,45 \mathrm{a}$ & $1,72 \mathrm{a}$ \\
20 ton/ha & $105,57 \mathrm{a}$ & $15,18 \mathrm{a}$ & $15,18 \mathrm{a}$ & $111,98 \mathrm{~b}$ & $2,86 \mathrm{~b}$ \\
40 ton/ha & $109,27 \mathrm{a}$ & $15,82 \mathrm{a}$ & $15,82 \mathrm{a}$ & $127,41 \mathrm{~b}$ & $3,79 \mathrm{c}$ \\
60 ton/ha & $107,77 \mathrm{a}$ & $16,28 \mathrm{a}$ & $16,28 \mathrm{a}$ & $108,71 \mathrm{bc}$ & $4,91 \mathrm{~d}$ \\
\hline $\mathrm{KK}=$ & $2,44 \%$ & $3,32 \%$ & $0.19 \%$ & $2.58 \%$ & $1.72 \%$ \\
\hline
\end{tabular}

Angka-angka dalam kolom yang sama yang diikuti oleh huruf kecil yang sama berbeda tidak nyata pada taraf $5 \%$ menurut DNMRT 
dan perlakuan 20 ton/ha dan perlakuan 60 ton/ha.

Terlihatnya perbedaan yang nyata karena pemberian abu batubara diberikan ke tanah selain meningkatkan ketersediaan $\mathrm{P}$ tanah, selain itu dapat juga menggiatkan pembentukan anakan yang sangat ditentukan oleh kegiatan pembelahan sel (Darwis, 1979).

\section{c. Berat 1000 Butir Gabah}

Dari Tabel 3 dapat dikatakan bahwa pengamatan terhadap berat butir gabah memperlihatkan pengaruh tidak nyata. Pengaruh yang tidak nyata terhadap berat 1000 butir gabah disebabkan karena masingmasing perlakuan menyumbangkan unsur hara, serta secara tidak langsung meningkatkan ketersediaan unsur hara di tanah, terutama unsur N,P,Ca dan $\mathrm{Mg}$ yang berguna bagi pertumbuhan fase generatif, seperti pembentukan biji dan proses pematangannya.

\section{d. Serapan P Tanaman (batang + daun)}

Dari Tabel 3 mempunyai pengaruh yang nyata antara tanpa perlakuan dengan masing-masing perlakuan yaitu perlakuan 20 ton/ha, perlakuan 40 ton/ha dan perlakuan 60 ton/ha, dan juga antar perlakuan perlakuan 20 ton/ha dengan perlakuan 60 ton/ha, tetapi perlakuan 20 ton/ha dengan perlakuan 40 ton/ha dan perlakuan 60 ton/ha mempunyai pengaruh tidak nyata sesamanya. Hal ini disebabkan karena adanya hasil analisis kimia setelah inkubasi didapat bahwa terjadi peningkatan ketersediaan $\mathrm{P}$ dengan peningkatan takaran abu batubara dan penurunan kandungan Al-dd serta peningkatan $\mathrm{pH}$ tanah, sehingga pertumbuhan tanaman menjadi lebih baik.

Kandungan Al yang tinggi dapat meracun bagi tanaman, yang mana akan menyebabkan gangguan fisiologis tanaman dan menyebabkan hambatan translokasi $\mathrm{P}$, sebagaimana yang dikemukakan oleh Nyakpa et al (1985), terhambatnya translokasi $\mathrm{P}$ akan menyebabkan terganggunya serapan $\mathrm{P}$ tanaman.
Selanjutnya Hakim (1982) menyatakan bahwa serapan $\mathrm{P}$ oleh tanaman meningkat sejalan dengan meningkatnya kelarutan $\mathrm{P}$ dan menurunnya kandungan Al-dd tanah. Serapan $\mathrm{P}$ oleh tanaman akan terganggu apabila Al-dd di dalam tanah tinggi.

\section{e. Serapan Silika Tanaman (batang + daun)}

Dari Tabel 3 mempunyai pengaruh yang nyata antara tanpa perlakuan dengan perlakuan 20 ton/ha, 40 ton/ha dan 60 ton/ha abu batubara. Peningkatan maksimum terjadi pada perlakuan 60 ton/ha, hal ini dikarenakan dari hasil analisis tanah didapat bahwa peningkatan $\mathrm{SiO}_{2}$ tanah seiring dengan peningkatan takaran abu batubara, hal ini juga berpengaruh terhadap $\mathrm{SiO}_{2}$ tanaman. Unsur Silika diserap tanaman dalam bentuk asam silisik $\left(\mathrm{H}_{4} \mathrm{SiO}_{4}\right)$, yang mana unsur ini sangat berperan dalam memperkuat dinding epidermis dan jaringan vaskular, mengurangi kekurangan air dan menghindari infeksi infeksi jamur.

\section{KESIMPULAN}

Dari hasil penelitian didapatkan kesimpulan sebagai berikut :

a) Pemberian abu batubara sebesar 60 ton/ha dapat meningkatkan beberapa sifat kimia tanah seperti peningkatan $\mathrm{pH}$, ketersediaan P, kation basa, Si tersedia dan penurunan kejenuhan Aluminium dan serapan $\mathrm{SiO}_{2}$ tanaman (batang dan daun).

b) Pemberian abu batubara sebesar 40 ton/ha dapat meningkatkan pertumbuhan tanaman, anakan produktif, berat 1000 butir gabah, dan serapan $\mathrm{P}$ tanaman (batang dan daun)

\section{UCAPAN TERIMA KASIH}

Pada kesempatan ini penulis mengucapkan terima kasih kepada Panitia Penelitian SP 4 dalam penyediaan dana untuk terlaksananya pelaksanaan penelitian dan juga kepada pihak yang telah membantu dalam pelaksanaan penelitian ini. 


\section{DAFTAR PUSTAKA}

Darmawan. 2005. Uji penggunaan abu sekam dan abu batu bara sebagai sumber silika bagi tanaman padi, suatu tantangan dan harapan di masa depan. Fakultas Pertanian Universitas Andalas. Padang. 7 halaman

Darwis,S.N. 1979. Agronomi Tanaman Padi. Lembaga Pusat Penelitian Pertanian Perwakilan Padang. 63 halaman

Hakim, N. M. Y. Nyakpa, A. M. Lubis, S. G. Nugroho, A. Diha, G. B. Hong dan H. H. Bailey. 1986. Dasardasar Ilmu Tanah. Universitas Lampung. 488 halaman

Hardjowigeno, S. 2003. Ilmu Tanah. Akademika Pressindo. Jakarta. 286 halaman

Hermansah. 1993. Ketersediaan dan serapan hara padi gogo dengan Pemberian Silikat dan Fosfat pada Oxisol. Karya Ilmiah Departemen Pendidikan dan Kebudayaan Pusat Pendidikan Univesitas Andalas Padang. 0 halaman. kedelai pada tanah podzolik merah kuning. Fakultass Pasca Sarjana Institut

Pertanian Bogor. Bogor. 83 halaman

Irmayanti.2000. Studi pemberian abu batubara pada tanah gambut terhadap sifat kimia tanah dan pertumbuhan serta hasil beberapa varietas kedelai (Glycine max (L) Merr). Skripsi Fakultas Pertanian Universitas Andalas. Padang. 50 halaman.

Komdorfer G and I.M. Lepsch. 2001. Effect of Silicon on Plant Growth and Crop Yield. In Silicon and Agriculture. Ed Datonof L, Komdorfer, Synder New York : Elvisier Science, pp 133 - 147

Sanchez, P. A. 1992. Sifat dan Pengelolaan Tanah Tropika jilid 2. Terjemahan Amir Hamzah dari Properties and Management of Soil in the Tropics. ITB. Bandung. 397 halaman

Sari,Y. 1998. Pengaruh waktu pemberian Sid an takaran $\mathrm{P}$ terhadap ketersediaan dan serapan $\mathrm{P}$ padi goo pada Oxisol Padang Siontah. Skripsi Fakultas Pertanian Universitas Andalas. Padang. 65 halaman.

Situmorang, R dan U. Sudadi. 2001. Tanah Sawah. Jurusan Tanah Fakultas Pertanian Institut Pertanian Bogor. Bogor. 104 halaman.

Soepardi. 1983. Sifat dan Ciri Tanah. Institut Pertanian Bogor. Bogor. 591 halaman. 